\title{
Commercial phenoxyacetic herbicides control heavy metal uptake by wheat in a divergent way than pure active substances alone
}

\author{
Elżbieta Skiba* ${ }^{*}$ and Wojciech M. Wolf
}

\begin{abstract}
Background: Impact of two widely used commercial herbicides, i.e. Aminopielik D 450 SL and Chwastox $300 \mathrm{SL}$, on the uptake and translocation of selected heavy metals in wheat plants Triticum aestivum L. cultivated in the laboratory pot experiments was investigated. Mineral-humus, loamy sand soil representative for the central part of Poland was applied. Bioavailable, exchangeable and total forms of $\mathrm{Cd}, \mathrm{Co}, \mathrm{Cu}, \mathrm{Zn}, \mathrm{Pb}$, and $\mathrm{Mn}$ were determined. Transfer coefficients, translocation, and bioaccumulation factors illustrating metal migration in the plant were investigated.

Results: Administration of commercial herbicides significantly altered heavy metals uptake by wheat in a way distinctively different than that observed for the parent chemically pure synthetic auxins, i.e. 2,4-D and MCPA. In particular, Aminopielik D 450 SL and Chwastox 300 SL prompted heavy metals accumulation in roots as indicated by their high transfer coefficients. Further transport to above ground part of the plant was limited and element dependent.
\end{abstract}

Conclusions: This work clearly shows that commercial herbicide formulations may act in a distinctively different way than pure active ingredients alone.

Keywords: Commercial herbicide formulations, 2,4-D, MCPA, Aminopielik, Chwastox, Triticum aestivum L., Heavy metals bioaccumulation and translocation

\section{Background}

Commercial herbicides are rarely pure active compounds. Nowadays, commonly used formulations contain supplementary ingredients which work as carriers, surfactants, stabilizers or dyes [1]. Those which enhance biological activity of herbicide are called adjuvants [2]. They are classified as activators and spray or utility modifiers and are added to herbicide either at the factory or field level. Today, more than 3000 adjuvants of diverse constituencies are offered on a market [3]. Additionally, formulations contain safeners which increase the herbicide selectivity between crop and weed species [4]. They show a wide range of affinities and selectivities towards

*Correspondence: elzbieta.skiba@p.lodz.pl

Institute of General and Ecological Chemistry, Lodz University of Technology, Żeromskiego 116, 90-924 Łódź, Poland heavy metals in soil. In particular, amines which are frequently present in commercial products are prone to interact with metals [5] and influence their uptake and absorption by the plant roots. Regrettably, investigations on heavy metal accumulation by agricultural plants under the presence of herbicides are focused on pure active substances [6]. Commercial formulations are examined scarcely [7]. This is difficult because according to current EU and US regulations $[8,9]$ chemical composition of additives is not to be mentioned on the product label and is usually bottled up by the manufacturers. They are obliged to specify the active substances of particular herbicide formulation only. This is a very uncomfortable situation because all ingredients are being introduced to the environment and their join impact cannot be properly assessed. Moreover, toxicity evaluations based on a single component can often lead to misleading conclusions [10]. 
The latter was proved by Mesnage et al. [8] who found that in certain circumstances organic adjuvants present in glyphosate-based herbicides were 10,000 times more toxic than active substance. We believe that this situation ought to be changed at the national and the EU legal level and manufacturers should publish the complete composition of all formulations in the market. Phenoxyacetic herbicides are synthetic auxins widely used in agriculture. They control broadleaf weeds by affecting growth of the plant's vascular tissue and are being often applied to protect grass and grain crops [11]. The most common representatives are 2,4-dichlorophenoxyacetic acid (2,4D) and 2-methyl-4-chlorophenoxyacetic acid (MCPA) [12]. They are active ingredients of two agrochemicals widely used in Europe, i.e. Aminopielik D 450 SL and Chwastox 300 SL.

In current work, impact of these two commercial formulations on the accumulation and distribution of heavy metals in Triticum aestivum L. plants was analysed and further compared to that induced by pure sodium salts of 2,4-D and MCPA as recently published by Skiba et al. [13]. To make this evaluation feasible, the soil and cultivation conditions were identical during this and former studies. To our knowledge, this is the first experimental work on the heavy metals uptake by wheat originated by commercial phenoxyacetic herbicide formulations widely used in agriculture.

\section{Methods}

\section{Soil}

The mineral-humus, loamy sand soil [14] was used for wheat cultivation. Samples were collected from the rural environment in the central Poland Skierniewice region $\left(51^{\circ} 97^{\prime} \mathrm{N}, 20^{\circ} 07^{\prime} \mathrm{E}\right)$. Procedure as described in the standard PN ISO 10381-4 was applied [15]. The same soil was used by us in the study of the heavy metals uptake induced by chemically pure 2,4-D and MCPA [13]. Soil was air-dried and sifted through a sieve with $2 \mathrm{~mm}$ mesh diameter and stored in plastic container. Soil $\mathrm{pH}$ was measured by the potentiometric method in $1 \mathrm{~mol} \mathrm{~L}^{-1}$ potassium chloride solution [16]. The gravimetric method for the determination of soil organic matter by the mass loss at $550{ }^{\circ} \mathrm{C}$ was applied [17]. The grain size analysis was performed according to the Polish Standard PN-R-04032 [18]. Exchangeable and bioavailable forms of metals were determined in $1 \mathrm{~mol} \mathrm{~L}{ }^{-1}$ solutions of $\mathrm{MgCl}_{2}$ and $\mathrm{HCl}$, respectively [19]. The total content of metals was evaluated by the soil decomposition method employing mixture of $\mathrm{H}_{2} \mathrm{SO}_{4}$ and $\mathrm{HF}$ [20].

\section{Herbicides}

Two commercial herbicide formulations were used in this study, namely Aminopielik 450 SL (PCC Rokita S.A.) and
Chwastox 300 SL (Ciech Sarzyna S.A.). Subsequently, they will be abbreviated as Aminopielik and Chwastox, respectively. The former contains in $1 \mathrm{~L} 417.5 \mathrm{~g}$ 2,4-D and $32.5 \mathrm{~g}$ dicamba (3,6-dichloro-2-methoxybenzoic acid) in the form of dimethylammonium salts. The latter is the sodium-potassium salt of MCPA supplied at the concentration $300 \mathrm{~g} \mathrm{~L}^{-1}$. Spray loads followed the field application rates as recommended by manufacturers, i.e. $3 \mathrm{~L} \mathrm{ha}^{-1}$. They correspond to 1.3 and $1.0 \mathrm{~kg} \mathrm{ha}^{-1}$ of chemically pure 2,4-D and MCPA, respectively.

\section{Wheat cultures}

High-quality Rywalka winter wheat (Triticum aestivum L.) seeds from PPH „Rolpuch” Co. LTD Kutno were used in the study. All plants were grown in pot experiments under the laboratory conditions following the procedure developed by Kobyłecka and Skiba [21]. Dry weight $400 \mathrm{~g}$ portions of soil were placed in rectangular $(17 \times 11 \mathrm{~cm})$ plastic pots of the height $6 \mathrm{~cm}$. The soil was further watered with $100 \mathrm{~mL}$ of deionized water. Wheat seeds $(20 \mathrm{~g})$ were sowed and covered with additional $100 \mathrm{~g}$ of soil. Pots were watered to keep the soil moisture in the range $5-10 \%$ and kept at temperature $20{ }^{\circ} \mathrm{C}$. Cultivation experiments were performed in two arrangements, each was related to one type of herbicide formulation. The third arrangement was cultivated as a reference without the addition of herbicides. A single batch consisted of cultures with five pots giving fifteen samples altogether. Sprays were applied in a week after sowing when the plants were in a stage 11 of either the Zadoks et al. [22] or BBCH [23] growth scales. Cultures were terminated after 3 weeks of growth (stage 13). The above ground parts of plants were cut while the roots were separated from soil by washing and rinsing with distilled water. The harvest was dried at $55{ }^{\circ} \mathrm{C}$, homogenized and further ground.

\section{Determination of metals in wheat shoots and roots}

The weighted plant subsamples $(0.7 \mathrm{~g}$-shoots and $0.5 \mathrm{~g}$-roots) were digested in the mixture of concentrated $\mathrm{HNO}_{3}(65 \%)$ and $\mathrm{H}_{2} \mathrm{O}_{2}(30 \%)(3: 1, \mathrm{v} / \mathrm{v})$ using the Anton Paar Multiwave 3000 closed system instrument. The content of $\mathrm{Cu}, \mathrm{Zn}$ and $\mathrm{Mn}$ was determined by the FAAS (GBC 932 plus) while $\mathrm{Pb}, \mathrm{Cd}$ and Co were analysed by the GFAAS (GBC, SensAA). The reliability of analytical procedures was checked using certified references materials: INCT-MPH-2 [24] and IAEA-V-10 [25].

\section{Statistical analysis}

A one-way analysis of variance ANOVA as implemented in OriginPro 2016 was used to test the impact of Aminopielik and Chwastox at 0.95 probability level. Numerical data are available from the authors on request. 


\section{Bioaccumulation, translocation and transfer factors}

Metal migration was evaluated by the transfer coefficient (TC) and bioaccumulation factor (BAF). They are ratios of particular element concentration in either root or shoot, related to its content in the soil [26]. Metal distribution inside plant body was assessed by the translocation factor (TF) which is the ratio of element concentration in above ground part of the plant to that in roots [27].

\section{Results and discussion}

Representative farmland soil from the central Poland was used in this study. Concentrations of metal forms as summarized in Additional file 1: Table S1 do not exceed the maximum allowable concentrations (MAC) and trigger action values (TAV) tabulated by Kabata-Pendias and Mukherje [28]. Bioavailable forms were identified for all metals with the largest contribution observed for lead and manganese. Exchangeable components of all species except cobalt were visible. The impact of Aminopielik and Chwastox on heavy metals accumulation was evaluated by the one-way ANOVA. Relevant data for chemically pure auxins 2,4-D and MCPA as determined by Skiba et al. [13] are given for comparison (Fig. 1). Metal contents in roots and shoots of wheat cultivated without and with herbicides treatment are given in the Additional file 2: Table S2. Aminopielik elevated concentrations of all metals in roots while 2,4-D was successful for zinc only.

a

\begin{tabular}{|c|c|c|c|c|}
\hline Metal & AMINOPIELIK & $2,4-D^{*}$ & CHWASTOX & MCPA* \\
\hline $\mathrm{Cd}$ & \$N⿴囗⿱ & & 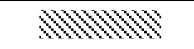 & $\$ \mathbb{N} \$$ \\
\hline Co & $\$ W$ & & & \\
\hline $\mathrm{Cu}$ & 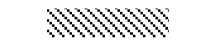 & & 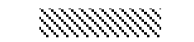 & 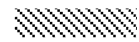 \\
\hline $\mathrm{Zn}$ & 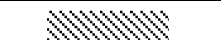 & 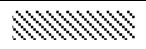 & «N & $\$$ \\
\hline $\mathrm{Mn}$ & Now & 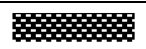 & (Now & 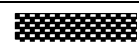 \\
\hline
\end{tabular}

b

\begin{tabular}{|c|c|c|c|c|}
\hline Metal & AMINOPIELIK & $2,4-D^{*}$ & CHWASTOX & MCPA* \\
\hline $\mathrm{Cd}$ & 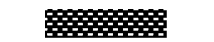 & 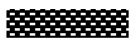 & 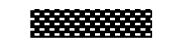 & 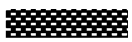 \\
\hline Co & ND & 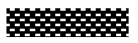 & ND & $\$ \cdots$ \\
\hline $\mathrm{Cu}$ & & 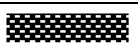 & & 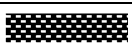 \\
\hline $\mathrm{Zn}$ & 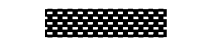 & & & $\$(\$$ \\
\hline $\mathrm{Mn}$ & WW & 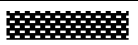 & Now & 咅 \\
\hline $\mathrm{Pb}$ & 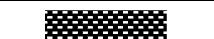 & 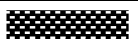 & 尛票 & \\
\hline
\end{tabular}

*Reference data for pure auxins as determined by Skiba et al. (2017)

Grey colour shows combination for which the average metal concentration in a plant tissue increases after the herbicide administration. Black colour represents decrease of respective metal concentration while white indicates no change. Concentrations below the detection limit are indicated by the acronym ND. The 0.95 probability level was applied for ANOVA calculations

Fig. 1 The influence of Aminopielik and Chwastox on heavy metals accumulation in wheat roots (a) and shoots (b). Asterisk reference data for pure auxins as determined by Skiba et al. [13]. Grey colour shows combination for which the average metal concentration in a plant tissue increases after the herbicide administration. Black colour represents decrease of respective metal concentration while white indicates no change. Concentrations below the detection limit are indicated by the acronym ND. The 0.95 probability level was applied for ANOVA calculations 
Cadmium, cobalt, copper and lead were left unchanged while the manganese content decreased upon the pure auxin administration. Chwastox increased cadmium, copper, zinc and manganese levels in roots, while cobalt and lead were left unchanged. Content of manganese decreased upon the MCPA treatment. More complicated picture was observed for shoots. Aminopielik decreased cadmium, zinc and lead concentrations. Copper level was unchanged while that of manganese was increased. The 2,4-D administration resulted in decreasing contents of all metals except zinc. Chwastox treatment gave effects distinctively different than those of MCPA for all metals except cadmium. Cobalt and zinc contents increased while copper and manganese levels decreased; lead was unchanged. On the contrary to pure 2,4-D and MCPA, both commercial herbicides prompted higher heavy metals accumulation in roots. This metal preconcentration was the most apparent for zinc as emphasized by its TCs which were higher than unity $(1.75,2.27$ for Aminopielik and Chwastox, respectively). Series of metals ordered according to decreasing TCs, TFs and BAFs calculated for plants treated with Aminopielik and Chwastox are summarized in Table 1; numerical data are in Additional file 3: Figure S1. Transfer coefficients determined for plants cultivated in the reference, untreated soil are in the order $\mathrm{Zn}>\mathrm{Cd}>\mathrm{Cu}>\mathrm{Pb}>\mathrm{Co}>\mathrm{Mn}$. Administration of Aminopielik, 2,4-D or Chwastox left that arrangement untouched. Treatment with the pure MCPA interchanged that order for lead and cobalt only. Nevertheless, commercial herbicides increased TCs for all metals investigated as compared to chemically pure auxins. Migration of metals in the plant body may be conveniently examined with the translocation factors. However, the emerging picture is more complex than that observed in roots. TFs for pure 2,4-D and MCPA are in the order $\mathrm{Mn}>\mathrm{Cu}>\mathrm{Zn}>\mathrm{Cd}>\mathrm{Co}>\mathrm{Pb}$ and $\mathrm{Mn}>\mathrm{Pb}>\mathrm{Cu}>\mathrm{Zn}>\mathrm{Cd}>\mathrm{Co}$, respectively. Aminopielik administration alters that arrangement for $\mathrm{Pb}, \mathrm{Cd}$ and Co while Chwastox interchanges positions of $\mathrm{Cu}$ and $\mathrm{Pb}$ only. Influence of Aminopielik on heavy metals uptake by roots is more pronounced than that of Chwastox. However, impact of both herbicides is much less clear in the above ground parts of the wheat plant. Both formulations hampered zinc transport to above ground parts of wheat and stabilized its accumulation in roots. The opposite effect was observed for manganese. Either Aminopielik or Chwastox mobilized this element within the plant body and significantly increased its concentration in shoots. On the contrary, either 2,4-D or MCPA administration led to accumulation and stabilization of manganese in roots alone. Aminopielik increased the lead accumulation in roots and reduced its further migration to the upper part of the plant in a more pronounced way than that of Chwastox. Variation of copper content in shoots was quite limited over all samples and followed the well-recognized low mobility of this element [29]. Cobalt and cadmium were scarcely present in soil. However, their uptake was facilitated by either Aminopielik or Chwastox and restricted to roots only.

\section{Conclusions}

This work is based on a more comprehensive approach to herbicide activity than that described by Skiba et al. [13]. On the contrary to that publication on the metal uptake upon the pure herbicide treatment, in this paper the special emphasis is put on the activity of commercial formulations practically used in agriculture. This issue is of particular relevance in view of increasing number of publications focused on toxicity originated from agrochemical ingredients and additives [30]. All living organisms may be affected with bees and other pollinators being the most prone [31-33].

Administration of two investigated commercial herbicide formulations significantly altered the heavy metals uptake by wheat. Their influence was distinctively different than that observed for the parent chemically pure synthetic auxins, i.e. 2,4-D and MCPA. In particular, they prompted higher metal uptake and their further accumulation in roots. However, the subsequent metals migration to the upper part of the plant was controlled by

Table 1 Series of metals ordered according to decreasing transfer coefficients (TC), translocation (TF) and bioaccumulation (BAF) factors

\begin{tabular}{|c|c|c|c|}
\hline Treatment & $\mathrm{TC}$ & TF & BAF \\
\hline Aminopielik & $\mathrm{Zn}>\mathrm{Cd}>\mathrm{Cu}>\mathrm{Pb}>\mathrm{Co}>\mathrm{Mn}$ & $\mathrm{Mn}>\mathrm{Cu}>\mathrm{Zn}>\mathrm{Pb}>\mathrm{Cd}>\mathrm{Co}^{\mathrm{a}}$ & $\mathrm{Zn}>\mathrm{Cu}>\mathrm{Mn}>\mathrm{Cd}>\mathrm{Pb}>\mathrm{Co}^{\mathrm{a}}$ \\
\hline $2,4-D$ & $\mathrm{Zn}>\mathrm{Cd}>\mathrm{Cu}>\mathrm{Pb}>\mathrm{Co}>\mathrm{Mn}$ & $\mathrm{Mn}>\mathrm{Cu}>\mathrm{Zn}>\mathrm{Cd}>\mathrm{Co}>\mathrm{Pb}$ & $\mathrm{Zn}>\mathrm{Cd}>\mathrm{Cu}>\mathrm{Mn}>\mathrm{Pb}>\mathrm{Co}$ \\
\hline Chwastox & $\mathrm{Zn}>\mathrm{Cd}>\mathrm{Cu}>\mathrm{Pb}>\mathrm{Co}>\mathrm{Mn}$ & $\mathrm{Mn}>\mathrm{Cu}>\mathrm{Pb}>\mathrm{Zn}>\mathrm{Cd}>\mathrm{Co}^{\mathrm{a}}$ & $\mathrm{Zn}>\mathrm{Mn}>\mathrm{Cu}>\mathrm{Cd}>\mathrm{Pb}>\mathrm{Co}^{\mathrm{a}}$ \\
\hline MCPA & $\mathrm{Zn}>\mathrm{Cd}>\mathrm{Cu}>\mathrm{Co}>\mathrm{Pb}>\mathrm{Mn}$ & $\mathrm{Mn}>\mathrm{Pb}>\mathrm{Cu}>\mathrm{Zn}>\mathrm{Cd}>\mathrm{Co}$ & $\mathrm{Zn}>\mathrm{Cd}>\mathrm{Cu}>\mathrm{Pb}>\mathrm{Co}>\mathrm{Mn}$ \\
\hline Reference & $\mathrm{Zn}>\mathrm{Cd}>\mathrm{Cu}>\mathrm{Pb}>\mathrm{Co}>\mathrm{Mn}$ & $\mathrm{Mn}>\mathrm{Pb}>\mathrm{Cu}>\mathrm{Cd}>\mathrm{Zn}>\mathrm{Co}$ & $\mathrm{Cd}>\mathrm{Zn}>\mathrm{Cu}>\mathrm{Pb}>\mathrm{Mn}>\mathrm{Co}$ \\
\hline
\end{tabular}

a Co content in shoots was below the detection limit (1 ppb); therefore, it was assumed that respective TFs and BAFs are zero

Results for untreated reference sample, 2,4-D and MCPA [13] are included for comparison 
Aminopielik and Chwastox in a less predictable way. The highest influence was observed for manganese and zinc while cadmium content in shoots decreased regardless to the type of applied herbicide.

Our results are in line with recent publications reporting that adjuvants activity extends far beyond the simple mechanics of herbicide application and adhesion. They may also affect biochemical processes responsible for metal uptake and translocation [34]. We therefore postulate that the usual activity and toxicity tests would involve herbicide formulations used in contemporary agriculture and not to be limited to their active ingredients alone. Moreover, the EU legislation and national regulations should bind the herbicide manufacturers and suppliers to publish the complete composition of all formulations they introduce in the market.

\section{Additional files}

Additional file 1: Table S1. General properties of soil (mean $\pm S D, n=$ 3) (a), Metal contents $\left(\mathrm{mg} \mathrm{kg}^{-1}\right)$ in soil (mean value $\pm S E, n=3$ ).

Additional file 2: Table S2. Metal contents with SE $\left(\mathrm{mg} \mathrm{kg}^{-1}\right)$ in roots and shoots of wheat cultivated without and with herbicides treatment.

Additional file 3: Figure S1. Transfer coefficients (TC) (a), translocation factors (TF) (b) and bioaccumulation factors (BAF) (c) of heavy metals in wheat untreated and under Aminopielik or Chwastox administration.

\section{Abbreviations}

2,4-D: 2,4-dichlorophenoxyacetic acid; MCPA: 2-methyl-4-chlorophenoxyacetic acid; $\mathrm{BBCH}$ : Biologische Bundesanstalt, Bundessortenamt und $\mathrm{CHemische}$ Industrie Cereal growth staging scales; FAAS: flame atomic absorption spectrometry; GFAAS: graphite furnace atomic absorption spectrometry; ANOVA: a one-way analysis of variance.

\section{Authors' contributions}

ES designed, carried out all experiments and did statistical analysis. WMW participated in manuscript preparation. Both authors read and approved the final manuscript.

\section{Acknowledgements}

The authors wish to thank Dr. Joanna Kobyłecka for her helpful discussion and useful hints related to chemical analysis of environmental samples.

The European University Foundation is acknowledged for advising on the legal and social dimension of this study.

\section{Competing interests}

The authors declare that they have no competing interests.

\section{Availability of data and materials}

Additional data are deposited as Additional files 1, 2 and 3.

\section{Consent for publication}

Not applicable.

Ethics approval and consent to participate

Not applicable.

\section{Funding}

This work received support from the statutory funds allocated to the Institute of General and Ecological Chemistry by the Polish Ministry of Science and Higher Education.

\section{Publisher's Note}

Springer Nature remains neutral with regard to jurisdictional claims in published maps and institutional affiliations.

Received: 16 May 2017 Accepted: 12 September 2017

Published online: 28 September 2017

\section{References}

1. Janků J, Bartovská L, Soukup J, Jursík M (2012) Density and surface tension of aqueous solutions of adjuvants used for tank-mixes with pesticides. Plant Soil Environ 58(12):568-572

2. Jursík M, Kolářová M, Soukup J, Ždárková V (2016) Effects of adjuvants and carriers on propoxycarbazone and pyroxsulam efficacy on Bromus sterilis in winter wheat. Plant Soil Environ 62(10):447-452

3. Pacanoski Z (2015) Herbicides and adjuvants. In: Price A, Kelton J, Sarunaite L (eds) Herbicides, physiology of action, and safety. Agric Biol Sci. doi:10.5772/60842. https://www.intechopen.com/books/herbicidesphysiology-of-action-and-safety/herbicides-and-adjuvants. Accessed 29 Apr 2017

4. Davies J (2001) Herbicide safeners - commercial products and tools for agrochemical research. Pestic Outlook 12:10-15. doi:10.1039/b100799h

5. Bradl H (ed) (2005) Heavy metals in the environment: origin, interaction and remediation. Elsevier, Amsterdam

6. Razu MH, Zaman S, Hasan MdA, Barai M, Hossain F, Mazumdar R, Khan M (2014) Effect of 2,4-dichlorophenoxy acetic acid on nutrients and heavy metals accumulation in wheat (Triticum durum) root. IJACS 7(7):214-219

7. Wang M, Zhou Q, Ren L (2009) Toxicological response in wheat Triticum aestivum under joint stress of chlorimuron-ethyl and copper. Ecotoxicol Environ Saf 72:2121-2129. doi:10.1016/j.ecoenv.2007.09.009

8. Mesnage R, Defarge N, Spiroux de Vendômois J, Séralini G-E (2014) Major pesticides are more toxic to human cells than their declared active principles. Biomed Res Int. Article ID 179691. doi:10.1155/2014/179691

9. Tu M, Hurd C, Randall JM (2001) Adjuvants. In: Tu M, Hurd C, Randall JM (eds) Weed control methods handbook: tools and techniques for use in natural areas. All US government documents (Utah Regional Depository). Paper 533

10. Heys KA, Shore RF, Pereira MG, Jones KC, Martin FL (2016) Risk assessment of environmental mixture effects. RSC Adv 6:47844-47857. doi:10.1039/ C6RA05406D

11. Monaco TJ, Weller SC, Ashton FM (2002) Weed science, Principles and practices. Wiley, New York

12. Eurostat (2007) The use of plant protection products use in the european union data 1992-2003, Statistical books. http://ec.europa.eu/eurostat/ documents/3217494/5611788/KS-76-06-669-EN.PDF. Accessed 29 Apr 2017

13. Skiba E, Kobyłecka J, Wolf WM (2017) Influence of 2,4-D and MCPA herbicides on uptake and translocation of heavy metals in wheat (Triticum aestivum L.). Environ Pollut 220:882-890. doi:10.1016/j.envpol.2016.10.072

14. PN-ISO 11259 (2001) Soil quality - a simplified description of the soil

15. PN-ISO 10381-4 (2007) Soil quality-sampling_-part 4: rules for procedure during the research areas of natural, semi-natural and cultivated sites

16. PN-ISO 10390 (1997) Soil quality-determination of pH

17. ASTM D2974-00 (2000) Standard test methods for moisture, ash, and organic matter of peat and other organic soils. Method D 2974-00. American Society for Testing and Materials. West Conshohocken

18. PN-R-04032 (1998) Soil and mineral minerals-sampling and determination of particle size distribution

19. Tessier A, Campbell PGC, Bisson M (1979) Sequential extraction procedures for the speciation of particulate trace metals. Anal Chem 51(7):844-851 
20. Ostrowska A, Gawliński S, Szczubiałka Z (1991) Methods of analysis and assesment of soil and plant properties. Institute of Environmental Protection-National Research Institute, Warsaw

21. Kobyłecka J, Skiba E (2008) The effect of phenoxyacetic herbicides on the uptake of copper, zinc and manganese by Triticum Aestivum L. Pol J Environ Stud 17(6):859-901

22. Zadoks JC, Chang TT, Konzak CF (1974) A decimal code for growth stages of cereals. Weed Res 14:415-421. doi:10.1111/j.1365-3180

23. Meier U (ed) (2001) Growth stages of mono- and dicotyledonous plants. BBCH monograph. Federal biological research centre for agriculture and forestry, Berlin. https://www.politicheagricole.it/flex/AppData/ WebLive/Agrometeo/MIEPFY800/BBCHengl2001.pdf. Access 29 Apr 2017

24. Dybczyński R, Danko B, Kulisa K, Maleszewska E, Polkowska-Motrenko H, Samczyński Z, Szopa Z (2004) Preparation and preliminary certification of two new Polish CRMs for inorganic trace analysis. J Radioanal Nucl Chem 259(3):409-413. doi:10.1023/B:JRNC.0000020909.67144.fC

25. Reference sheet IAEA-V-10. https://nucleus.iaea.org/rpst/Documents/ rs_iaea-v-10.pdf. Access 29 Apr 2017

26. Chen H, Yuan X, Li T, Hu S, Ji J, Wang C (2016) Characteristics of heavy metal transfer and their influencing factors in different soil-crop systems of the industrialization region, China. Ecotoxicol Environ Saf 126:193-201. doi:10.1016/j.ecoenv.2015.12.042

27. Shi G, Cai Q (2009) Cadmium tolerance and accumulation in eight potential energy crops. Biotechnol Adv 27:555-561. doi:10.1016/j. biotechadv.2009.04.006
28. Kabata-Pendias A, Mukherje AB (2007) Trace elements from soil to human. Springer, Berlin

29. Bose S, Bhattacharyya AK (2008) Heavy metal accumulation in wheat plant grown in soil amended with industrial sludge. Chemosphere 70:1264-1272. doi:10.1016/j.chemosphere.2007.07.062

30. Benuszak J, Laurent M, Chauzat M-P (2017) The exposure of honey bees (Apis mellifera; Hymenoptera: Apidae) to pesticides: room for improvement in research. Sci Total Environ 587-588:423-438. doi:10.1016/j. scitotenv.2017.02.062

31. Bünemann EK, Schwenke GD, Van Zwieten L (2006) Impact of agricultural inputs on soil organisms-a review. Aust J Soil Res 44:379-406. doi:10.1071/SR05125

32. Ciarlo TJ, Mullin ChA, Frazier JL, Schmehl DR (2012) Learning impairment in honey bees caused by agricultural spray adjuvants. PLoS ONE 7(7):e40848. doi:10.1371/journal.pone.0040848

33. Mullin ChA, Chen J, Fine JD, Frazier M, Frazier JL (2015) The formulation makes the honey bee poison. Pestic Biochem Phys 120:27-35. doi:10.1016/j.pestbp.2014.12.026

34. Chuah TS, Tan PK, Ismail BS (2013) Effects of adjuvants and soil microbes on the phytotoxic activity of coumarin in combination with p-vanilin on goosegrass (Eleusine indica L.) seedlings emergence and growth. S Afr J Bot 84:128-133. doi:10.1016/j.sajb.2012.11.003

\section{Submit your manuscript to a SpringerOpen ${ }^{\circ}$ journal and benefit from:}

- Convenient online submission

$\checkmark$ Rigorous peer review

- Open access: articles freely available online

- High visibility within the field

- Retaining the copyright to your article

Submit your next manuscript at $\boldsymbol{\nabla}$ springeropen.com 